\title{
RUCH TURYSTYCZNY NA TERENIE MIASTA I GMINY ZLOCIENIEC
}

\section{LE MOUVEMENT TOURISTIQUE SUR LE TERRAIN DE LA VILLE ET DE LA COMMUNE DE ZŁOCIENIEC THE TOURIST TRAFFIC IN THE CITY AND DISTRICT OF ZŁOCIENIEC}

W artykule zaprezentowano charakter ruchu turystycznego na terenie miasta i gminy Złocieniec. Podstawowym celem pracy była odpowiedź na pytanie: kto, gdzie i kiedy odwiedza miasto i gminę Złocieniec oraz jakie są potrzeby, wymagania i oczekiwania przyjeżdżających? Artykuł składa się z trzech części: w pierwszej przedstawiono walory turystyczne badanego obszaru, $w$ drugiej stan zagospodarowania turystycznego, a w trzeciej ruch turystyczny. Badania przeprowadzono przy zastosowaniu metod wywiadu kwestionariuszowego, kart inwentaryzacyjnych oraz kwerendy w instytucjach. Pozwolilo to na wieloaspektową charakterystyke przedmiotu badań ${ }^{1}$.

Problem ruchu turystycznego nie jest nowym zagadnieniem w literaturze geograficznej. Od lat prowadzone są badania nad ruchem turystycznym na różnych obszarach. Współcześnie, w dobie szybko zachodzących przekształceń społeczno-gospodarczych i politycznych badania te nabierają nowego charakteru.

Celem opracowania jest próba sformułowania odpowiedzi na pytanie kto, gdzie i kiedy odwiedza miasto i gminę Złocieniec? jakie sa gusty, wymagania i oczekiwania gości? jakie winno to mieć konsekwencje w planowaniu strategii promocji tego obszaru?

${ }^{1}$ Na przelomie lat 1995/96 w Katedrze Geografii Miast i Turyzmu UŁ została wykonana przez Elżbietę Porę praca magisterska zawierająca monograficzny opis zagadnień z zakresu rozwoju turystyki na terenie miasta i gminy Złocieniec. Prezentowane opracowanie jest jednym z rozdzialów tej pracy. 


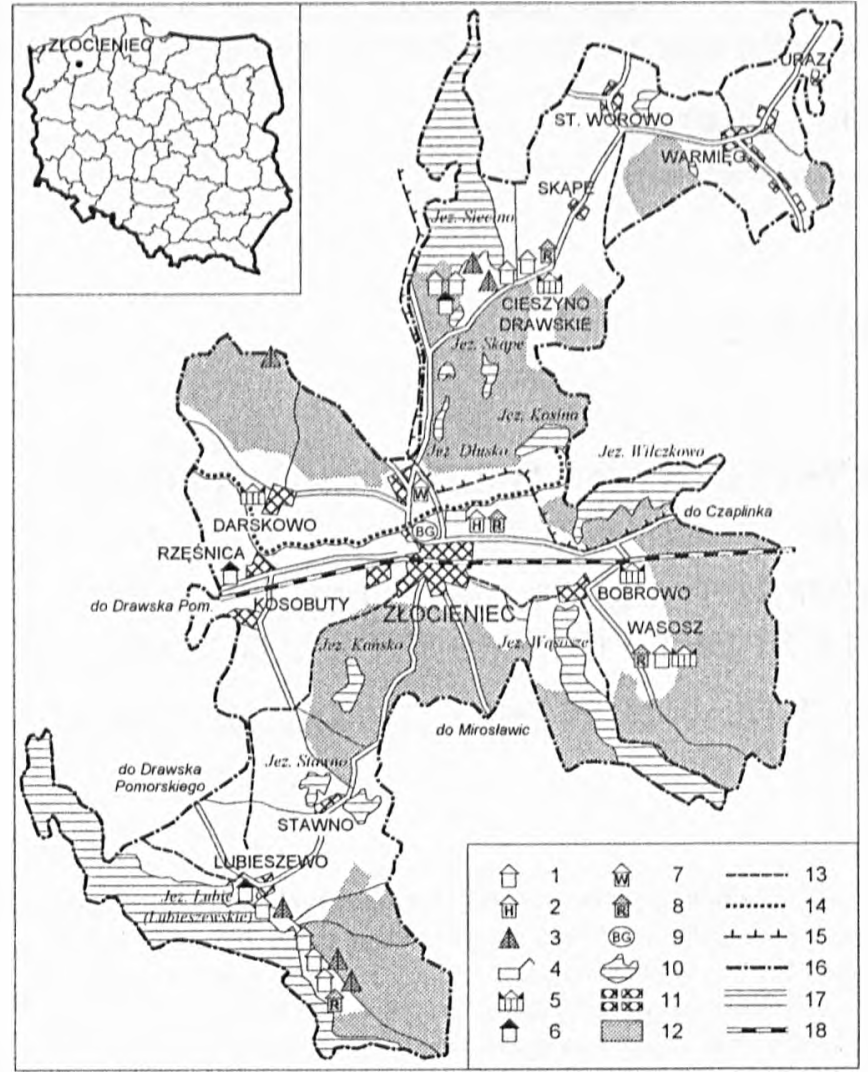

Rys. 1. Atrakcyjność turystyczna miasta i gminy Zlocieniec

1 - ośrodki wypoczynkowe, 2 - hotele, 3 - kempingi i pola namiotowe, 4 -schroniska młodzieżowe, 5 - palace i dwory, 6 - pokoje gościnne, 7 - stanice wodne, 8 - baza gastronomiczna, 9 - baza gastronomiczna poza ośrodkami wypoczynkowymi, 10 - szlaki turystyczne, 11 - szlaki wodne, 12 - granice Drawieńskiego Parku Krajobrazowego, 13 - granice gminy, 14 - lasy, 15-drogi, 16 - linia kolejowa, 17 - jeziora, 18 - miasto

Dessin 1. L'attraction touristique de la ville et de la commune de Zlocieniec 1 - centres de repos, 2 - hôtels, 3 - campings et champs de tentes, 4 - abris pour la junesse, 5 - palais et manoirs, 6 - chambres d'hôte, 7 - abris au bord des eaux, 8 - base gastronomique des centres de repos, 9 - base gastronomique hors les centres de repos, 10 - itinéraires touristiques, 11 - itinéraires sur eau, 12 - limite, 13 - limite de la commune, 14 - forêts, 15 - chemins, 16 - ligne ferroviaire, 17 - lacs, 18 - ville

Materiał źródłowy zebrano w okresie lipca i sierpnia 1995 r. poprzez badania kwestionariuszowe (130 ankiet przeprowadzono w punktach o największym natężeniu ruch turystycznego), kwerendę terenową w instytucjach administracyjnych (Urząd Miasta i Gminy Złocieniec, Urząd Wojewódzki w Koszalinie i in.) i usługodawców turystycznych (ośrodki bazy noclegowej i gastronomicz- 
nej) oraz poprzez bezpośrednią obserwację w terenie. Tak zebrany materiał źródłowy daje wystarczająca podstawę empiryczną do realizacji postawionego celu badawczego.

\section{ATRAKCYJNOŚĆ TURYSTYCZNA}

Wielkość, lokalizacja, sezonowość, struktura i motywacje do uczestnictwa w ruchu turystycznym są wypadkową składników tworzących atrakcyjność turystyczną obszaru.

Miasto i gmina Złocieniec są położone na terenie Pojezierza Drawskiego. $\mathrm{Z}$ obserwacji i prowadzonych badań wynika, że głównym walorem turystycznym są tutaj elementy środowiska przyrodniczego: wody powierzchniowe, szata leśna i ukształtowanie powierzchni (rys. $1^{2}$ ).

Szczególną rolę odgrywają jeziora i rzeki. To właśnie one wraz $\mathrm{z}$ ich najbliższym otoczeniem stanowią podstawę rozwoju różnych form turystyki na badanym terenie.

Wody powierzchniowe zajmują w gminie Złocieniec ok. $31,81 \mathrm{~km}^{2}$, co stanowi $16,4 \%$ powierzchni całego obszaru. Wśród wód dominuja jeziora, których jest na terenie gminy 21, w tym pięć dużych: Lubie, Siecino, Wilczkowo, Wąsosze i Kańsko, o powierzchni przekraczającej 300 ha każde. Z rzek gminy najważniejsza jest Drawa i jej dopływ Kokna, będące naturalnymi szlakami kajakowymi.

Dla rekreacji i wypoczynku największe znaczenie ma nie tylko sama obecność zbiorników wodnych, ale też ich wielkość, dostępność linii brzegowej, morfometria brzegów, stan czystości wód, szata roślinna w bezpośrednim otoczeniu brzegów zbiornika. Biorąc pod uwagę wyżej wymienione czynniki najlepsze warunki dla użytkowania turystycznego mają największe jeziora gminy Złocieniec, a mianowicie Siecino, Wilczkowo, Lubie i Wąsosze.

Poza wymienionymi zbiornikami wodnymi, na terenie gminy Złocieniec występuje wiele mniejszych jezior nie nadających się dla turystyki pobytowej, ale posiadające bardzo interesujące walory krajoznawcze, np. jezioro Czarnówek, jezioro Morzysław Mały (rezerwaty przyrody) i jezioro Skape.

Lasy w gminie Złocieniec zajmują ok. $70,87 \mathrm{~km}^{2}$, co stanowi $36,43 \%$ powierzchni badanego obszaru. Dominują zbiorowiska borowe, a najczęściej występującym gatunkiem jest sosna. Przydatność borów dla turystyki jest zróżnicowana i należy ją rozpatrywać z różnych punktów widzenia (Ko s t r o w i c k a 1997). Przede wszystkim lasy te mają duże znaczenie klimatyczne i to zarówno

${ }^{2}$ Wszystkie zamieszczone w tym artykule rysunki opracowane zostały przez autorkę, a wykonane komputerowo przez mgr Annę Wosiak. 
w skali całego regionu, jak i w skali lokalnej (znaczenie wiatrochronne, tlenotwórcze, wydzielanie olejków eterycznych itd.). Ze względu na wydzielanie olejków eterycznych lasy odgrywają ważną rolę w lecznictwie. Ponadto ważna jest także ich funkcja krajobrazowa, szczególnie dla form wędrownych turystyki.

Bardzo duże znaczenie dla rozwoju turystyki ma również ukształtowanie powierzchni.

Na terenie gminy Złocieniec występuje krajobraz młodoglacjalny odznaczający się świeżością form, których późniejsze procesy denudacyjne nie zdołały zniwelować. Charakterystycznym elementem krajobrazu są wały i pagórki moren czołowych powstałe w czasie dłuższego postoju lądolodu, a także morena denna (falista i płaska) oraz sandry. Pomimo że na terenie gminy Złocieniec nie ma ciągu wzgórz czołowomorenowych, niemniej jednak ich zasięg dociera do północnych krańców badanego terenu. W północnej i południowo-zachodniej części gminy Złocieniec występuje morena pagórkowata tworząca charakterystyczny pofałdowany krajobraz, który jest pokryty niedużymi kompleksami leśnymi, co tworzy doskonałe warunki widokowe; jest to obszar predestynowany do uprawiania turystyki rowerowej i wędrówkowej. Wysokości wahają się w granicach od 130 m n.p.m. do 167,1 m n.p.m. (wysokość względna - 37,1 m). Tereny pagórkowate występują również na zachód i południe od miasta Złocieńca, a także na wschód od jeziora Lubie. Wysokości bezwzględne n.p.m. i względne osiagają na wymienionych obszarach jedne z najwyższych wartości w całej gminie Złocieniec, które wynoszą: na wschód od jeziora Lubie od $116,7 \mathrm{~m}$ n.p.m. do $176,3 \mathrm{~m}$ n.p.m. (wysokości względne $56,9 \mathrm{~m}$ ) i na poludnie od Złocieńca od 130 m n.p.m. do 171,3 m n.p.m. (wysokości względne 32,5 m). Najwyższy punkt wysokościowy to góra Sarnki - 181 m n.p.m. - w solectwie Bobrowo.

Dodatkową atrakcją turystyczną badanego obszaru jest Drawski Park Krajobrazowy, (DPK) który zajmuje ponad 50\% terenu gminy Złocieniec. Powołano go w celu ochrony najcenniejszych pod względem przyrodniczym i krajobrazowym fragmentów Pojezierza Drawskiego, o wyjątkowo zróżnicowanej konfiguracji terenu, bogatej florze i faunie, licznych jeziorach. Dzięki tak różnorodnemu bogactwu walorów przyrodniczych stwarza on doskonałe warunki do uprawiania różnego rodzaju form turystyki krajoznawczej (spacery, wycieczki, bieganie, jazda na rowerze).

Na terenie DPK znajdują się dwa interesujące rezerwaty przyrody: „Torfowisko nad Jeziorem Morzysław Mały” (rezerwat florystyczny) i „Jezioro Czarnówek" (rezerwat wodno-florystyczny) z unikalnym w skali Polski stanowiskiem lobelii jeziornej.

Zasoby kulturowe w gminie Złocieniec nie mają tak wysokiej rangi jak walory przyrodnicze, niemniej jednak ich znaczenie w ruchu turystycznym jest istotne. Na szczególną uwagę zasługują zabytkowe pałace w Darskowie, Cieszynie Drawskim i Bobrowie, parki z drzewostanem pomnikowym, kościoły baro- 
kowe w Darskowie i Lubieszewie, kościoły ryglowe w Cieszynie Drawskim i Starym Worowie oraz cmentarze ewangelickie. Interesujące są również całe układy przestrzenne wsi, miasta Złocieńca (układ ulic w centrum miasta przetrwał w niezmienionym stanie od czasów średniowiecza) i ich zabudowa. Jest to tym bardziej ciekawe, że walory antropogeniczne badanego regionu są pozostałością architektury niemieckiej. W swojej formie i stylu są odmienne od tego, co można zaobserwować w innych regionach Polski.

\section{STAN ZAGOSPODAROWANIA TURYSTYCZNEGO}

Istotnym elementem umożliwiającym właściwe korzystanie z walorów przyrodniczych i antropogenicznych badanego obszaru jest zagospodarowanie turystyczne. W skład zagospodarowania turystycznego wchodzą: baza noclegowa, gastronomiczna, komunikacyjna i towarzysząca.

W 1995 r. na terenie gminy Złocieniec zarejestrowano 14 obiektów noclegowych i dwie kwatery z pokojami gościnnymi (tab. I).

Baza noclegowa skoncentrowana jest $w$ czterech solectwach: Cieszyno Drawskie (5 obiektów), Lubieszewo (5), Bobrowo (2), Rzęśnica (1) i mieście Złocieńcu (3). Ogólna liczba miejsc noclegowych wynosi 1717 (w bazie stałej 1177, na kempingach i polach namiotowych - 540). Największą liczbą miejsc noclegowych dysponują: sołectwo Cieszyno Drawskie 901, Lubieszewo 516, Bobrowo 160, miasto Złocieniec 125, Rzęśnica 15. Przeprowadzone badania dowiodły, że turyści przyjeżdżający na teren gminy Złocieniec preferują nocleg w domkach kempingowych i ośrodkach wypoczynkowych. Zmniejsza się natomiast liczba amatorów pól namiotowych i kempingowych. Dowodzi to, że 540 miejsc noclegowych na kempingach i polach namiotowych jest liczbą wystarczającą i każdy kto przyjedzie na teren gminy Złocieniec z własnym namiotem bądź przyczepą bez trudu znajdzie zakwaterowanie.

Znacznie gorzej przedstawia się sytuacja noclegów w bazie stałej. Liczba 1177 miejsc noclegowych jest wartością niewystarczająca, a na nocleg mogą liczyć jedynie ci turyści, którzy odpowiednio wcześniej zarezerwują miejsca w wybranym ośrodku (tzn. w marcu lub w kwietniu). Dochodzi do tego, że goście kończący urlop, w dniu wyjazdu płacą za domek za rok następny. Jest to poważny problem, a jednocześnie wskazówka dla decydentów z terenu miasta i gminy Złocieniec o potrzebie budowy nowych ośrodków turystycznych, najlepiej małych, wkomponowanych w krajobraz lasów, jezior i pagórków morenowych.

Istnieje jeszcze problem standardu ośrodków turystycznych. W obecnych czasach nie wystarczy już tylko łóżko, stolik i „trzy krzesła”. Oczekiwania turystów są znacznie wyższe i idą w kierunku stworzenia w miejscu noclegu wa- 
Obiekty noclegowe turystyki na terenie miasta i gminy Zlocieniec

Les bases touristiques de couchage sur le terrain de la ville et de la commune de Złocieniec

\begin{tabular}{|c|c|c|c|c|c|}
\hline \multirow{2}{*}{$\begin{array}{l}\text { Miejsco- } \\
\text { wość }\end{array}$} & \multirow{2}{*}{ Obiekt } & \multicolumn{2}{|c|}{ Czas działania } & \multirow{2}{*}{$\begin{array}{l}\text { Liczba } \\
\text { miejsc } \\
\text { nocle- } \\
\text { gowych }\end{array}$} & \multirow{2}{*}{$\begin{array}{c}\text { Baza } \\
\text { żywieniowa } \\
\text { rodzaj, } \\
\text { liczba miejsc }\end{array}$} \\
\hline & & sezonowy & $\begin{array}{l}\text { calo- } \\
\text { roczny }\end{array}$ & & \\
\hline \multirow{5}{*}{$\begin{array}{l}\text { I. } \\
\text { Cieszyno } \\
\text { Drawskie }\end{array}$} & $\begin{array}{l}\text { Ośrodek Wczasowy } \\
\text { „Ekoland” }\end{array}$ & $\begin{array}{l}\text { czerwiec- } \\
\text { wrzesień }\end{array}$ & - & 140 & $\begin{array}{c}\text { stołówka } \\
70\end{array}$ \\
\hline & $\begin{array}{l}\text { Ośrodek Wypoczynkowy } \\
\text { Exbud SA Kielce }\end{array}$ & $\begin{array}{l}\text { czerwiec- } \\
\text { wrzesień, } \\
\text { obiekt } \\
\text { zamknięty }\end{array}$ & - & 15 & $\begin{array}{l}\text { stołówka } \\
20\end{array}$ \\
\hline & $\begin{array}{l}\text { Ośrodek Wypoczynku } \\
\text { Świątecznego, Kemping } \\
\text { nr 240, jez. Siecino }\end{array}$ & $\begin{array}{l}15 \text { czerwca- } \\
15 \text { września }\end{array}$ & - & 318 & $\begin{array}{l}\text { restauracja } \\
160\end{array}$ \\
\hline & $\begin{array}{l}\text { Ośrodek Kempingowy } \\
\text { „Drawa” }\end{array}$ & $\begin{array}{l}\text { czerwiec- } \\
\text { wrzesień }\end{array}$ & - & 88 & brak \\
\hline & $\begin{array}{l}\text { Ośrodek Kolonijno- } \\
\text { Wczasowy }\end{array}$ & - & tak & 342 & $\begin{array}{c}\text { jadalnia } \\
200 \\
\text { kawiarnia } \\
40 \\
\end{array}$ \\
\hline \multirow[t]{3}{*}{$\begin{array}{l}\text { II } \\
\text { Ztocieniec }\end{array}$} & Hotel „Kibic”, kat. II & - & tak & 33 & $\begin{array}{c}\text { restauracja } \\
50 \\
\end{array}$ \\
\hline & Stanica Wodna nad Drawa & - & tak & 42 & $\begin{array}{l}\text { restauracja } \\
80 \\
\end{array}$ \\
\hline & $\begin{array}{l}\text { Schronisko Młodzieżowe } \\
\text { PTSM }\end{array}$ & $\begin{array}{l}\text { lipiec- } \\
\text { sierpień }\end{array}$ & - & 50 & brak \\
\hline \multirow{4}{*}{$\begin{array}{l}\text { III } \\
\text { Lubieszewo }\end{array}$} & Pokoje gościnne & - & tak & 8 & brak \\
\hline & $\begin{array}{l}\text { Ośrodek Wędkarski przy } \\
\text { Petrochemii SA Plock }\end{array}$ & $\begin{array}{l}\text { czerwiec- } \\
\text { wrzesień }\end{array}$ & - & 70 & brak \\
\hline & $\begin{array}{l}\text { Ośrodek Wypoczynkowy } \\
\text { ZDZ Złocieniec }\end{array}$ & $\begin{array}{c}\text { czerwiec- } \\
\text { sierpień }\end{array}$ & - & 66 & brak \\
\hline & $\begin{array}{l}\text { Ośrodek Wypoczynkowy } \\
\text { „Lubie” }\end{array}$ & $\begin{array}{l}\text { czerwiec- } \\
\text { wrzesień }\end{array}$ & - & 140 & brak \\
\hline $\begin{array}{l}\text { Lubieszewo } \\
\text { (Zatonie) }\end{array}$ & $\begin{array}{l}\text { Młodzieżowy Ośrodek } \\
\text { Kościoła Adwentystów } \\
\text { Dnia 7-go }\end{array}$ & - & tak & 180 & $\begin{array}{c}\text { stołówka } \\
100 \\
\text { (dania wege- } \\
\text { tariańskie) }\end{array}$ \\
\hline $\begin{array}{l}\text { IV } \\
\text { Wąsosz }\end{array}$ & $\begin{array}{l}\text { Ośrodek kolonijno-wczasowy } \\
\text { „Wifama”-Lódź }\end{array}$ & $\begin{array}{l}15 \text { czerwca- } \\
15 \text { września } \\
+ \text { ferie } \\
\text { zimowe } \\
\end{array}$ & - & 110 & $\begin{array}{c}\text { jadalnia } \\
120\end{array}$ \\
\hline V & Kemping nad jez. Wilczkowo & $\begin{array}{l}\text { czerwiec- } \\
\text {-sierpień }\end{array}$ & - & 50 & brak \\
\hline VI Rzęśnica & Pokoje gościnne & - & - & 15 & brak \\
\hline
\end{tabular}

Ź r ó d l o: Badania własne, 1995 r. 
runków domowych. Właściciele i dzierżawcy obiektów noclegowych wychodzą naprzeciw wymaganiom turystów podnosząc standard domków kempingowych i pokoi gościnnych. Obecnie coraz więcej ośrodków na terenie gminy Złocieniec wyposażonych jest w oddzielne aneksy kuchenne, łazienki, prysznice i toalety.

Przeprowadzone ankiety przeczą zatem powszechnie panującej tezie, że w wyniku ogólnej pauperyzacji społeczeństwa turysta szuka jak najtańszego sposobu spędzenia urlopu (co wiąże się bezpośrednio z tanią bazą noclegowa). $\mathrm{Na}$ terenie gminy Złocieniec tendencja jest zupełnie inna, nie jak najtańszy nocleg, ale niedrogi i komfortowy.

Elementem niezbędnym do prawidłowego rozwoju ruchu turystycznego jest istnienie obok bazy noclegowej zaplecza gastronomicznego.

W 1995 r. łączna pojemność bazy gastronomicznej na terenie gminy Złocieniec wynosiła 1253 miejsc, z czego na bazę ogólnodostępną przypadło 478 miejsc, a na bazę zamknięta (w obiektach turystycznych) 775 miejsc. Baza gastronomiczna poza ośrodkami wczasowymi skoncentrowana jest prawie w całości w mieście Złocieńcu (dwie restauracje, sześć kawiarni, trzy bary) i tylko jeden bar we wsi Lubieszewo. Ogólnodostępna baza gastronomiczna występuje w 11 spośród 16 ośrodków wczasowych. W celu określenia stopnia rozwoju bazy gastronomicznej posłużono się wskaźnikiem wyrażającym stosunek liczby turystów do liczby miejsc konsumenckich. Dla terenu miasta i gminy Złocieńca wskaźnik rozwoju bazy gastronomicznej wynosi 6,7 i jest przy obecnym stanie bazy noclegowej wystarczający. Nie ma zatem potrzeby zwiększania liczby miejsc konsumenckich. Jak już wspomniano, na badanym obszarze dąży się do stworzenia domowych warunków zakwaterowania i zamiast jednej wspólnej stołówki domki kempingowe wyposażone są $\mathrm{w}$ aneksy kuchenne $\mathrm{z}$ butlą gazową oraz drobnym sprzętem gospodarstwa domowego (szklanki, naczynia, sztućce), z których każdy turysta może korzystać bez żadnych ograniczeń.

Goście nie korzystający z usług gastronomii albo korzystający z nich tylko częściowo, mogą przyrządzić posiłki kupując w sklepach niezbędne produkty żywnościowe. W 1995 r. funkcjonowało na terenie miasta Złocieńca 21 sklepów spożywczych, dziewięć mięsno-wędliniarskich, siedem warzywno-owocowych (oraz cztery budki warzywno-owocowe typu ,szczęki”). Poza tym w każdej wsi sołeckiej znajdował się przynajmniej jeden sklep spożywczo-przemysłowy.

Nie mniej istotne znaczenie dla obsługi ruchu turystycznego mają urządzenia bazy towarzyszącej. Są to urządzenia oraz instytucje o charakterze usługowym, handlowym, rozrywkowym, kulturalnym, sportowym, zaspokajające rozmaite potrzeby życiowe turystów, a nawet stanowiące pewne dodatkowe walory turystyczne, bądź też umożliwiające wykorzystanie walorów podstawowych. Do urządzeń turystycznych występujących na terenie gminy Złocieniec zaliczamy: kąpielisko, wypożyczalnie sprzętu wodnego, korty tenisowe, boiska do gry w piłkę nożną, siatkówkę, sale gimnastyczne, sauny i świetlice. Wszystkie wymienione elementy znajdują się na terenie obiektów turystycznych i dostęp do nich 
mająjedynie goście wypoczywający w danym ośrodku (ogólnodostępne są jedynie kappieliska). Brak ogólnodostępnych urządzeń turystycznych stanowi poważny problem gdyż uniemożliwia właściwe wykorzystanie walorów przyrodniczych gminy Złocieniec. Dotyczy to przede wszystkim ogólnodostępnych wypożyczalni sprzętu wodnego (bez których nie może być mowy o uprawianiu turystyki wodnej) i kapielisk. Zbyt mała liczba miejsc przystosowanych do plażowania i kapieli nie tylko pogarsza warunki wypoczynku ale przyczynia się do powstawania dzikich plaż, które stanowić mogą poważne zagrożenia dla środowiska przyrodniczego.

Bardzo duże znaczenie dla ruchu turystycznego mają szlaki turystyki pieszej, ponieważ umożliwiają one poznanie najpiękniejszych i najciekawszych regionów miasta i gminy Złocieniec. Przez badany obszar przebiega pięć szlaków turystycznych (rys. 1): Szlak Przyrodniczy (czarny, długości 70,7 km), Szlak Jezior (zielony - 56,7 km), Szlak Wału Pomorskiego (czarny - 29,4 km), Szlak im. 1 Warszawskiej Brygady Kawalerii (niebieski - 51,9 km, Szlak Jezior Drawskich (zielony - $84 \mathrm{~km}$ ). Z pięciu wymienionych szlaków tylko Szlak Przyrodniczy i Szlak Jezior, znajdujące się na terenie Drawskiego Parku Krajobrazowego, są dobrze oznakowane, czytelne i ułatwiają sprawne poruszanie się po terenie. Pozostałe są nieczytelne, źle oznakowane i nie tylko utrudniają wędrówki turystów po gminie Złocieniec, a wręcz mogą ich dezorientować i wprowadzić w błąd. Zachodzi zatem konieczność ponownego oznakowania szlaku i ustawienia tablic informacyjnych o przebiegu trasy i o tym, co ciekawego można zobaczyć na badanym obszarze.

Poza szlakami turystyki pieszej przez teren miasta i gminy Złocieniec przebiegają dwa szlaki wodne: szlak kajakowy po rzece Drawie im. ks. Kardynała Karola Wojtyły (długości 195 km), jeden z najpiękniejszych szlaków wodnych w Polsce, i szlak kajakowy Kokny (dopływ Drawy) - o długości 13 km, o znaczeniu lokalnym.

Bazę towarzyszącą uzupełnia sieć komunikacyjna, którą tworzą drogi kołowe i kolejowe. Połączenia kolejowe reprezentuje tylko jedna linia Drawsko Pomorskie-Złocieniec-Szczecinek, która służy jedynie jako szlak dojazdowy do Złocieńca. Na trasie kolei znajdują się trzy stacje kolejowe: główna w Złocieńcu oraz dwie mniejsze, w Rzęśnicy i Bobrowie, o znaczeniu lokalnym. W ostatnich latach obserwuje się regres połączeń i linii kolejowej. Na terenie gminy Złocieniec zlikwidowano połączenie Złocieniec-Cieszyno Drawskie-Połczyn Zdrój. Jest to tym bardziej niekorzystne zjawisko, że od Złocieńca do Połczyna Zdrój trasa przebiegała przez najbardziej interesujące i urozmaicone krajobrazowo fragmenty gminy Złocieniec, co mogłoby stanowić dodatkową atrakcję turystyczną.

Wobec braku połączeń kolejowych turyści mogą korzystać z sieci dróg kołowych. Ogółem na terenie miasta i gminy Złocieniec znajduje się $62 \mathrm{~km}$ dróg utwardzonych, przeważnie o nawierzchni asfaltowej. Od 11 lat ich stan tech- 
niczny ulegał poważnemu pogorszeniu, co dotyczy szczególnie dróg lokalnych. Przez środek badanego obszaru równolegle z linią kolejową przebiega droga nr 174 relacji Drawsko Pomorskie-Złocieniec-Czaplinek-Szczecinek.

Cechą charakterystyczną sieci dróg kołowych jest to, że rozchodzą się one koncentrycznie od centrum miasta Złocieńca. Brak jest natomiast połączeń drogami lokalnymi utwardzonymi, między wsiami. $Z$ jednej osady wiejskiej do drugiej można się dostać z pominięciem miasta Złocieńca jedynie drogami gruntowymi, które w trudnych warunkach atmosferycznych są zwykle nieprzejezdne dla pojazdów kołowych. Zły stan dróg kołowych ma niekorzystny wpływ na rozwój turystyki. Szczególnie niepokojąca jest sytuacja w południowej części gminy nad jeziorem Lubie. Do ośrodków turystycznych zlokalizowanych w południowo-wschodniej części jeziora prowadzi tylko jedna droga gruntowa, od wielu lat nie remontowana.

Podstawę komunikacji kołowej stanowi sieć połączeń autobusowych. Główna stacja PKS znajduje się w Złocieńcu. Stąd można dotrzeć do siedmiu z dziewięciu wsi soleckich na badanym terenie. Brak jest połączeń z wsiami Darskowo i Bobrowo, które zlikwidowano kilka lat temu. Jest to bardzo niekorzystna sytuacja, ponieważ do najbliższego przystanku trzeba iść pieszo ok. $2-3 \mathrm{~km}$. Wobec niedostatecznej ilości połączeń autobusowych najlepszym środkiem lokomocji jest własny samochód bądź rower, który umożliwia dotarcie do najbardziej odległych zakątków miasta i gminy Złocieniec.

\section{RUCH TURYSTYCZNY}

Z przeprowadzonych badań wynika, że w okresie od września 1994 r. do końca sierpnia 1995 r. zarejestrowano na terenie miasta i gminy Złocieniec ok. 8406 turystów (dane z kart obiektów turystycznych i kart meldunkowych). Przypuszcza się jednak, że ruch turystyczny jest znacznie większy i wynosi od 10 do 12 tys. gości rocznie (łącznie z wizytami nie zarejestrowanymi).

Interesujący obraz rozmieszczenia turystów na terenie miasta i gminy Złocieniec daje zastosowanie metody koncentracji do analizy badanego zjawiska. Obliczony współczynnik Lorentza ${ }^{3}$, wynoszący 0,453 , świadczy o umiarkowanej koncentracji. Jak wynika z rys. 2 , najwięcej turystów wypoczywa na terenie solectwa Cieszyno Drawskie $(34,6 \%)$ i Lubieszewo $(35,1 \%)$, a następnie miasta Złocieniec $(24,3 \%)$, stosunkowo najmniej gości odwiedza sołectwa Bobrowo $(5,2 \%)$ i Rzęśnica $(0,8 \%)$. Brak turystów notuje się w pięciu z dziewięciu sołectw, czyli w ponad połowie.

${ }^{3}$ Wspólczynnik koncentracji Lorentza obliczono na podstawie wzoru $K=a:(a+b)$, gdzie $K$ oznacza stosunek powierzchni zawartej pomiędzy krzywą koncentracji a linią równomiernego podziału do ogólnej powierzchni trójkąta (na podstawie K r z y s z t o f i a k, U r b a n e k 1981). 


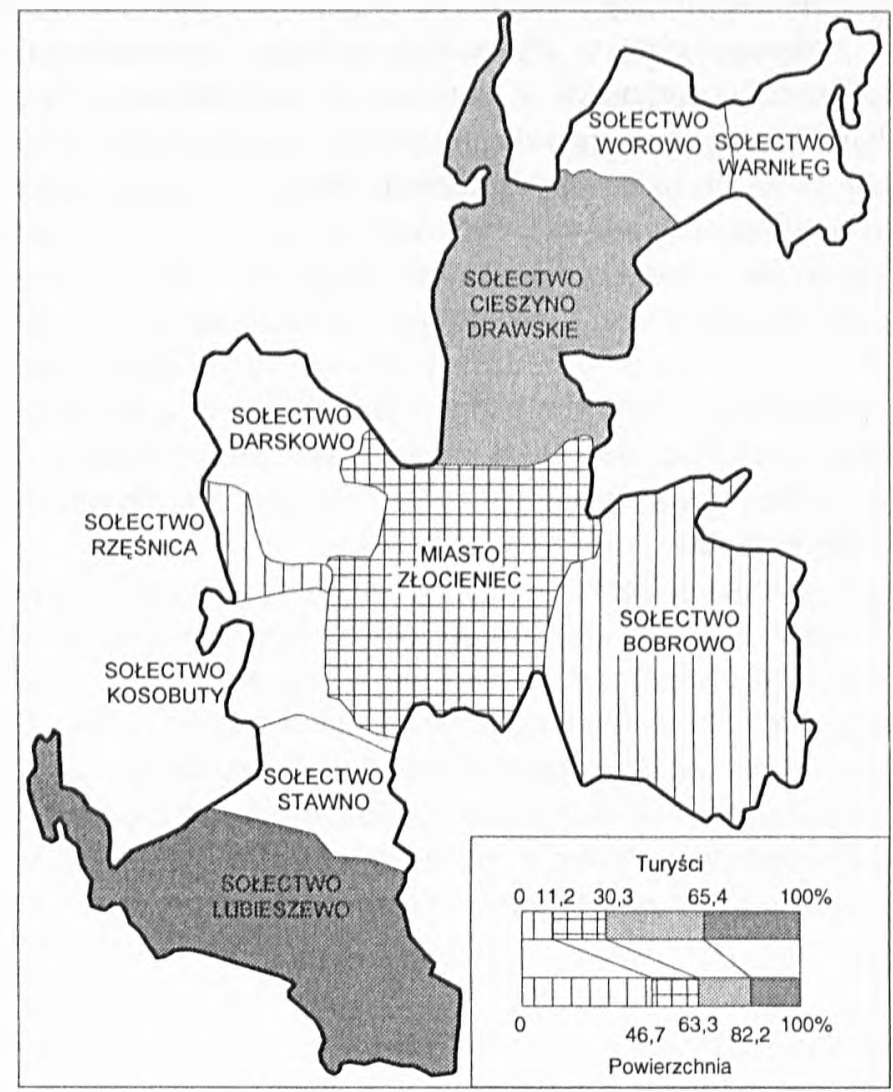

Rys. 2. Mapa koncentracji rozmieszczenia turystów na terenie miasta i gminy Złocieniec

Dessin 2. La carte de concentation de la disposition des touristes sur le terrain de la ville et de la commune de Zlocieniec

Nie jest to zjawisko przypadkowe, ale ściśle związane z rozmieszczeniem bazy noclegowej i warunkami środowiska przyrodniczego korzystnymi dla wypoczynku. Najlepsze warunki występują bowiem w sołectwach Cieszyno Drawskie i Lubieszewo, położonymi nad dużymi zbiornikami wodnymi Siecino i Lubie, gdzie występuja doskonałe warunki do uprawiania turystyki wodnej $\mathrm{i}$ innych związanych z nią form wypoczynku. Znaczna też liczba turystów odwiedza miasto Złocieniec, atrakcyjne ze względu na swoje malownicze położenie nad Drawą, naturalnym szlakiem wodnym. Pozostałe sołectwa nie są odpowiednio przystosowane do wizyt gości, stąd też mała liczba turystów albo ich brak.

Przyjazdy turystów na badany obszar charakteryzują się wyraźnymi zmianami sezonowymi. W celu uchwycenia sezonowych wahań wizyt turystów w mieś- 
cie i gminie Złocieniec, posłużono się wskaźnikiem sezonowości obliczonym na podstawie średniej miesięcznej liczby odwiedzających:

$$
\text { wskażnik sezonowości }=\frac{\text { liczba turystów w miesiqcu }}{\text { średnia miesięczna liczba turystów }} \times 100 \%
$$

Biorąc za podstawę liczbę 8406 turystów, obliczono, że średnio w miesiącu wypoczywało na badanym obszarze 700,5 osoby. Obliczone na tej podstawie wskaźniki sezonowości dla poszczególnych miesięcy w roku wykazują duże odchylenia od wartości średniej (rys. 3).

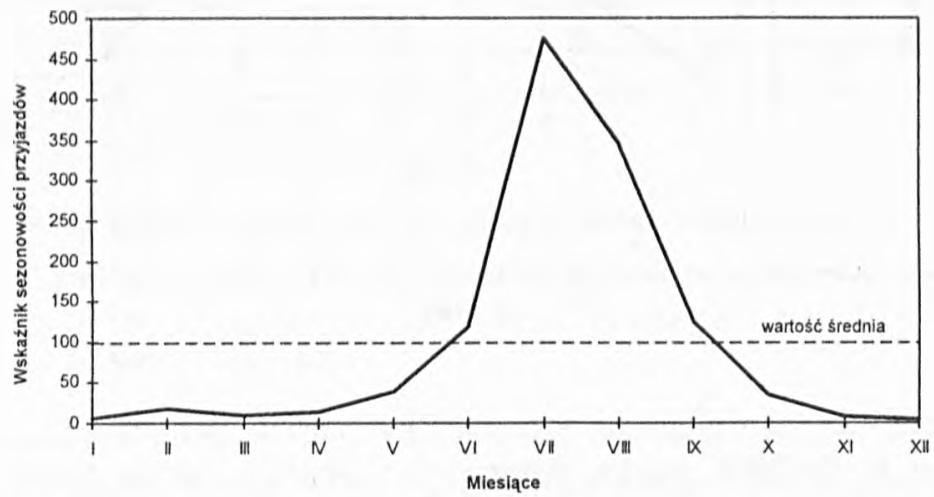

Rys. 3. Wskaźnik sezonowości przyjazdów turystów na teren gminy Złocieniec w 1995 r.

Dessin 3. L'étalon du caractére saisonnier des arrivées des touristes sur le terrain de la commune de Zlocieniec en 1995

Tylko w ciągu czterech miesięcy wartość wskaźnika jest wyższa od średniej miesięcznej. Wyraźne maksimum przyjazdów notuje się w lipcu (wartość wskaźnika 475,1\%), kolejne, ale już niższe w sierpniu (347,3\%). W czerwcu i wrześniu wskaźnik przyjazdów jest prawie identyczny i wynosi $118,5 \%$ dla czerwca i $124,3 \%$ dla września. Od stycznia do maja i od października do grudnia wizyty gości osiągają wartości minimalne i nie przekraczają nawet $40 \%$ średniej miesięcznej.

Sezonowość w ruchu turystycznym na terenie gminy Złocieniec związana jest głównie z czynnikami przyrodniczymi i społeczno-ekonomicznymi. Wysokie średnie miesięczne temperatury lata, długie dni, duże nasłonecznienie, obfitość jezior i możliwość uprawiania sportów wodnych to główne elementy predestynujące ten obszar do wypoczynku letniego. $Z$ czynników ekonomicznych największe znaczenie mają terminy wakacji, tradycja wykorzystywania urlopów 
latem, a przede wszystkim baza noclegowa, która przystosowana jest do okresu ciepłego.

Istotnym elementem charakteryzującym ruch turystyczny jest średnia długość pobytu turystów na badanym obszarze (rys. 4).

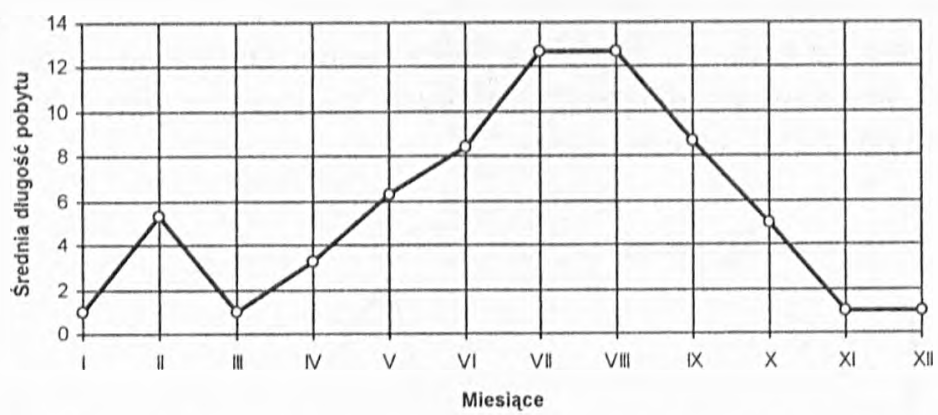

Rys. 4. Średnia dlugość pobytu turystów na terenie gminy Złocieniec w $1995 \mathrm{r}$.

Dessin 4. La longueur moyenne du séjour des touristes sur le terrain de la commune de Zlocieniec en 1995

Najdłużej turyści przebywają w gminie Złocieniec w lipcu i sierpniu (12,7 dni), a najkrócej w styczniu, marcu, listopadzie i grudniu (jeden dzień). Dłuższe pobyty występuja jeszcze w lutym, kiedy średnia ich długość wynosi 5,3 dni. Związane jest to $\mathrm{z}$ terminem ferii zimowych i przyjazdem młodzieży szkolnej na wypoczynek (ferie w lutym organizowane są w ośrodku w Wasoszy i w ośrodku Zakładu Energetycznego „Legnica” SA w Cieszynie Drawskim). Prezentowane wartości średniej długości pobytu podkreślają jeszcze raz, że na terenie gminy Złocieniec dominuje turystyka letnia, pobytowa, związana bezpośrednio z walorami przyrodniczymi badanego obszaru.

W badaniu ruchu turystycznego bardzo duże znaczenie mają motywy, jakimi kierują się goście odwiedzający dany obszar (tab. II).

Na podstawie badań ankietowych stwierdzono, że głównym motywem i celem przyjazdu turystów na teren gminy Złocieniec były walory przyrodnicze $(18,1 \%)$, bądź takie, które bezpośrednio od walorów przyrodniczych zależą (turystyka kwalifikowana - $13,7 \%$, ucieczka od cywilizacji - $17,5 \%$, zmiana środowiska $-15,1 \%$, razem $64,4 \%$ ). Gminę Złocieniec w blisko $2 / 3$ odwiedzają stali goście. Dla $62,3 \%$ ankietowanych jest to kolejna wizyta - zwykle siódma $(38,3 \%)$, bądź druga $(24,7 \%)$. Świadczy to o tym, że kto raz tu przyjedzie, z chęcią wraca tu ponownie. A powrót do gminy Złocieniec powoduja przede wszystkim walory przyrodnicze $(95 \%)$ i tu na pierwszym miejscu turyści wymieniają wodę, las i czyste powietrze, czyli te elementy, które stanowią główną atrakcję turystyczną tego obszaru. 
Motywy i cele przyjazdu turystów na teren gminy Zlocieniec w $1995 \mathrm{r}$.

Les motifs et les buts d'arrivées des touristes sur le terrain de la commune de Złocieniec en 1995

\begin{tabular}{|l|c|c|}
\hline \multirow{2}{*}{ Motywy } & \multicolumn{2}{|c|}{ Liczba odpowiedzi } \\
\cline { 2 - 3 } & wartość bezwzględna & $\%$ \\
\hline Walory przyrodnicze & 106 & 18,1 \\
Walory antropogeniczne & 11 & 1,9 \\
Turystyka kwalifikowana & 80 & 13,7 \\
Ucieczka od cywilizacji & 102 & 17,5 \\
Bliskość miejsca zamieszkania & 18 & 3,1 \\
Chęć poznania nowego terenu & 27 & 4,6 \\
Zmiana środowiska & 88 & 15,1 \\
Przyzwyczajenie & 27 & 4,6 \\
Miejsce polecane przez znajomych & 38 & 6,5 \\
Moźliwość wypoczynku z calą rodziną & 57 & 9,8 \\
Względy rodzinne & 12 & 2,0 \\
Dobre zagospodarowanie terenu & 8 & 1,4 \\
Inne & 10 & 1,7 \\
\hline Razem & 584 & 100,0 \\
\hline
\end{tabular}

Ź r ó d l o: Badania wlasne, 1995 r.

Formami turystyki (tab. III) preferowanymi przez osoby przebywające na terenie gminy Złocieniec są kąpiele (18,9\%), plażowanie (17,5\%), wędrówki piesze $(15,2 \%)$, wędkarstwo (12,7\%) i żeglarstwo (3,0\%). Aż 74,8\% odpowiedzi związanych jest więc $\mathrm{z}$ walorami przyrodniczymi tego terenu, a dokładnie z wypoczynkiem nad woda.

Analizując odpowiedzi turystów próbowano znaleźć związki między motywami przyjazdu, formami wypoczynku, a wiekiem, płcią i wykształceniem gości. Niestety, w wymienionych przypadkach nie wystąpiły żadne wyraźne zależności. Związane jest to przede wszystkim ze specyfiką tego terenu, a dokładnie z tym, że do gminy Złocieniec jedzie się (jeździ się) „po” walory przyrodnicze bez względu na płeć, wiek i wykształcenie. Jeżeli turysta szuka dyskotek, pubów, ekskluzywnych restauracji, drogich hoteli i mocnych wrażeń, to na omawianym terenie tego nie znajdzie. Do gminy Złocieniec jeździ się po to, aby w sposób świadomy i rozsądny korzystać z walorów przyrodniczych tego terenu, a zagospodarowanie turystyczne w postaci bazy towarzyszącej (pomosty, kąpieliska, szlaki turystyczne, wypożyczalnie sprzętu wodnego) ma umożliwić turystom jak najlepsze spędzenie wolnego czasu w bliskim kontakcie z natura, kontakcie, który nie zniszczy tego pięknego zakątka Polski.

Analizując wiek odwiedzających, formy turystyki, miejsca noclegów i miejsca żywienia opracowano profil turysty wypoczywającego na badanym obsza- 
rze. W gminie Złocieniec dominuje wypoczynek rodzinny. Główną grupę odwiedzających stanowią turyści między 30 a 50 rokiem życia $-72,4 \%$. Są to przede wszystkim rodzice z dziećmi i dziadkowie z wnukami. Mieszkają w przyczepach kempingowych lub namiotach na polach namiotowych $(53,1 \%)$ lub w ośrodkach wypoczynkowych $(19,2 \%)$, a posiłki przyrządzają we własnym zakresie $68,6 \%$. Ulubionymi formami turystyki uprawianymi przez tę grupę ludzi są wspomniane wyżej plażowanie, kąpiele, wędkarstwo, wędrówki piesze.

T a b e l a III

Formy turystyki uprawiane przez turystów podczas pobytu na terenie gminy Złocieniec w $1995 \mathrm{r}$.

Les formes de tourisme pratiquées par les touristes pendant leur séjour sur le terrain de la commune de Zlocieniec en 1995

\begin{tabular}{|l|c|c|}
\hline \multirow{2}{*}{ Formy turystyki } & \multicolumn{2}{|c|}{ Liczba odpowiedzi } \\
\cline { 2 - 3 } & wartość bezwzględna & $\%$ \\
\hline Plażowanie & 105 & 17,5 \\
Kapiele & 113 & 18,9 \\
Wędrówki piesze & 91 & 15,2 \\
Jazda na rowerze & 19 & 3,2 \\
Bieganie & 4 & 0,6 \\
Wycieczki krajoznawcze & 42 & 7,0 \\
Zeglarstwo & 18 & 3,0 \\
Kajakarstwo & 45 & 7,5 \\
Wędkarstwo & 76 & 12,7 \\
Grzybobranie & 19 & 3,2 \\
Wypoczynek bierny & 57 & 9,5 \\
Inne & 10 & 1,7 \\
\hline Razem & 599 & 100,0 \\
\hline
\end{tabular}

Ź r ó d ł o: Badania wlasne, 1995 r.

Rysunek 5 przedstawia koncentrację miejsc zamieszkania turystów wypoczywających na terenie gminy Złocieniec.

Obliczony współczynnik Lorentza, wynoszący 0,87 , świadczy o bardzo nierównomiernym rozkładzie przestrzennym miejsc stałego zamieszkania gości na terenie kraju. Najwięcej osób przyjechało z województwa łódzkiego, a następnie z województwa koszalińskiego. Kolejny przedział to województwa: legnickie, katowickie, bielskie, poznańskie, wrocławskie, krakowskie i słupskie. Najmniej turystów wypoczywających na badanym terenie pochodzi z województw: częstochowskiego, płockiego, warszawskiego, szczecińskiego, gorzowskiego, bydgoskiego, opolskiego, lubelskiego, zielonogórskiego i kieleckiego. Turyści przyjeżdżający do Złocieńca mieszkają tylko w 21 województwach, skoncentro- 
wanych w zachodniej części Polski. Blok wschodni reprezentuje tylko województwo lubelskie. Interesujący jest fakt, że najwięcej turystów przyjeżdża z województw o największej liczbie ludności, silnie uprzemysłowionych i zanieczyszczonych (łódzkie, katowickie, bielskie, krakowskie, wrocławskie, legnickie). Zjawisko to tłumaczy się tym, że z wyżej wymienionych województw istnieje większa potrzeba wyjazdu. Turyści szukają terenów o czystym, niezanieczyszczonym środowisku, gdzie moga w pełni zregenerować siły psychofizyczne nadszarpnięte uciążliwymi warunkami życia w dużych ośrodkach miejsko-przemysłowych. Ściana wschodnia to przede wszystkim województwa o niskim stopniu zurbanizowania i rozwoju przemysłu, przeważnie rolnicze. Brak bądź małą frekwencję turystów tłumaczyć można niewielką potrzebą wyjazdu lub (dotyczy to zwłaszcza silnie zurbanizowanego województwa warszawskiego) bliskością Pojezierza Wschodniopomorskiego.

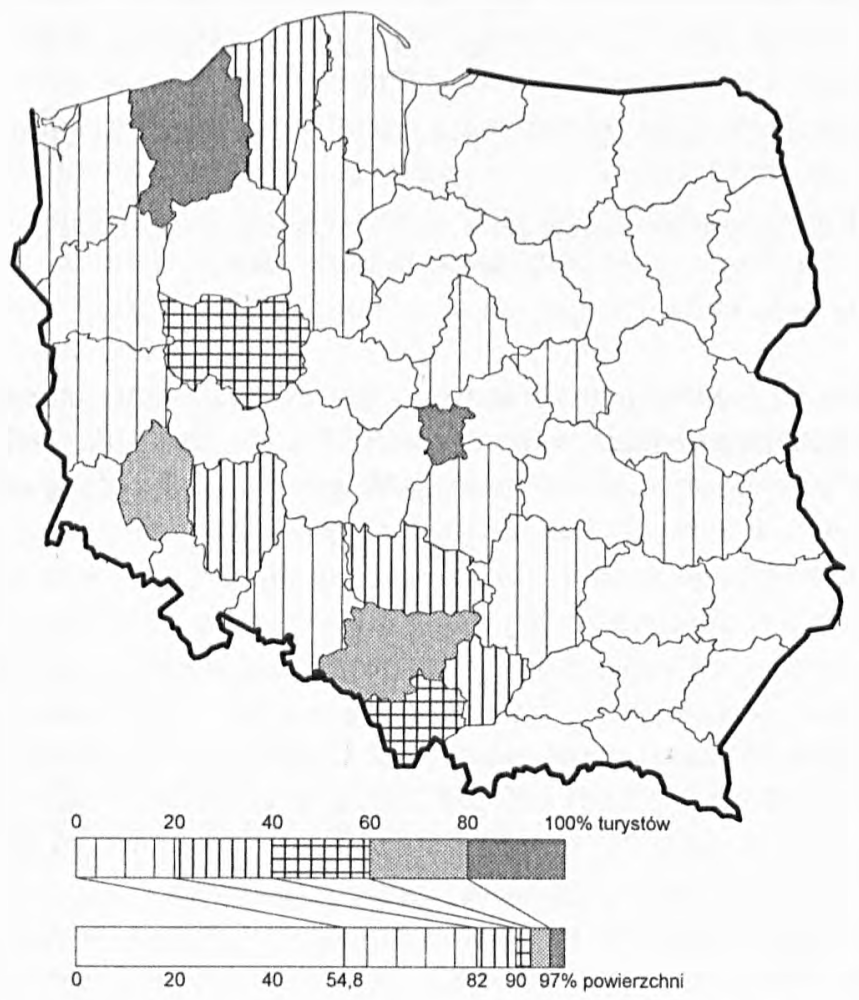

Rys. 5. Mapa koncentracji miejsc zamieszkania turystów wypoczywających na terenie miasta i gminy Złocieniec

Dessin 5. La carte de concentration des lieux d'habitation des touristes se reposant sur le terrain de la ville et de la commune de Zlocieniec 
Rozkład przyjazdów turystów z poszczególnych stref odległości od Złocieńca (rys. 6) pozwala wyznaczyć trzy pola rynkowe: regionalne do $150 \mathrm{~km}$, aglomeracji miejsko-przemysłowych położonych bliżej $(350-400 \mathrm{~km})$ i dalej $(500$ $550 \mathrm{~km})$.

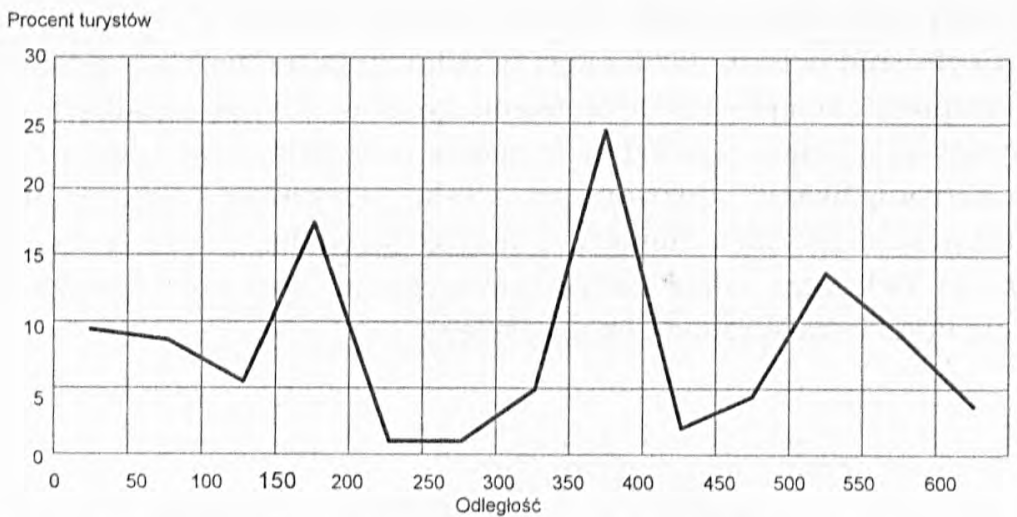

Rys. 6. Rozkład przyjazdów turystów z poszczególnych stref odległości od miasta Złocieńca w $1995 \mathrm{r}$.

Dessin 6. La disposition des arrivées des touristes des zones particulierès de l'éloignement de la ville de Zlocieniec en 1995

Pierwsze regionalne pole rynkowe to odwiedzający z gmin sąsiednich, przyjeżdżający autobusem bądź własnym samochodem na krótki, jednodniowy lub weekendowy wypoczynek nad jezioro. W grupie tej znajdują się także osoby z województw ościennych. Ich przyjazd do gminy Złocieniec wiąże się z bliskim położeniem badanego terenu, jak również z niechęcią i pewną opieszałością ludzi do poszukiwania oraz odkrywania nowych zakątków Polski. Drugie i trzecie pole rynkowe to odwiedzający z dużych aglomeracji miejsko-przemysłowych (łódzkie, wrocławskie, legnickie, katowickie i częstochowskie), charakteryzujących się dużą uciążliwością życia. Ucieczka od cywilizacji i możliwość przebywania przez kilka bądź kilkunaście dni w zdrowym, kontrastowym wobec własnego miejsca zamieszkania środowisku przyrodniczym to główne motywy przyjazdu na wypoczynek do miasta i gminy Złocieniec.

Poza turystami krajowymi badany obszar odwiedzają również goście z zagranicy. W 1995 r. stanowili oni 3,8\% badanych respondentów. Obcokrajowcy przyjechali z Niemiec i z Holandii - po dwie osoby i jedna z Kanady. Przyjazdy Niemców można określić jako tzw. turystykę sentymentalną, związaną z miejscem urodzenia bądź pochodzenia przodków. 


\section{WNIOSKI}

W ostatnich latach, obok naukowego wzrasta również praktyczne zastosowanie badań ruchu turystycznego. Szczególnie ważna jest ich rola w promocji turystycznej gminy. Promocja tworząca właściwy image pełni najważniejszą funkcję $w$ marketingu. Do niedawna była prawie nieznana na tym terenie, a w epoce turystyki socjalnej wręcz niepotrzebna. Od kilku lat władze gminy i właściciele obiektów turystycznych starają się przyciagnąć na własny teren jak najwięcej turystów. Nie jest to łatwy proces, bo trzeba wiedzieć, gdzie promować, jak, co i dla kogo. Na te pytania można znaleźć odpowiedź prowadząc badania ruchu turystycznego na konkretnym obszarze. Szczególnie istotne znaczenie mają te opracowania, które dotyczą wymagań i oczekiwań turystów, pozwalają bowiem na właściwe gospodarowanie walorami turystycznymi obszaru, tak aby jak najbardziej uatrakcyjnić wypoczynek. Ważne jest również, gdzie wypoczywają goście. Znając odpowiedź na to pytanie można poprawić warunki pobytu na jednym obszarze, a inny zaktywizować. Chyba jednak najwięcej uwagi należy zwrócić na to skąd pochodzą turyści odwiedzający miasto i gminę Złocieniec. Znajomość tego zagadnienia umożliwi bowiem właściwą promocję wewnętrzną (krajowa) i zewnętrzną (zagraniczna) terenu. Pozwoli to $\mathrm{z}$ jednej strony na bardziej wnikliwe poznanie przez turystów obszaru, a z drugiej umożliwi im dotarcie do miejsc, gdzie walory turystyczne tej części Pojezierza Drawskiego są jeszcze nieznane albo informacje na jego temat są zbyt mało interesujące, aby spędzić tam urlop.

Badania ruchu turystycznego są tym w geografii, czym badania rynku w naukach ekonomicznych. Bez tych badań nie ma odpowiedniego wizerunku obszaru, nie ma promocji, a w końcu właściwego rozwoju turystyki.

\section{PIŚMIENNICTWO}

K r z y s z t o f i a k M., U r b a n e k D., 1981, Metody statystyczne, PWN, Warszawa.

M a t c z a k A., 1992. Model badań ruchu turystycznego. Studium metodologiczne, Ut, Łódź.

Materiały statystyczne zaczerpnięte z Urzędu Miasta i Gminy Zlocieniec.

P o r a - K a b a t h E., 1996, Stownik geograficzno-turystyczny miasta i gminy Zlocieniec, maszynopis pracy magisterskiej, Katedra Geografii Miast i Turyzmu UŁ, Łódź.

S zw i c h t e n b e rg A., 1995, Gospodarstwa turystyczne w okresie przejściowym, Wyższa

Szkoła Inżynierska, Koszalin. 


\section{RÉSUMÉ}

Dans l'article on a presenté le caractère du mouvement touristique sur le terrain de la ville et de la commune de Złocieniec. L'élaboration a eu pour but la réponse à la question qui, où et quand visite la ville et la commune de Złocieniec et quels sont les besoins, les exigences et les attentes des touristes?

Comment peuvent-ils se réfléter dans la planification de la structure de promotion de ce terrain.

Les matériels de source étaient accumulés aux mois de juillet et d'août 1995. Pour les amasser, on faisait des recherches d'enquête (130 enquêtes aux points de l'intensification suprême du mouvement touristique), on quérissait dans les institutions administratives (municipalité de ville et de commune, offices de voïvodie à Koszalin, etc.) et dans celles rendant services touristiques (centres de la base de couchage et gastronomique). On observait aussi le terrain.

La ville et la commune de Złocieniec sont situées sur le terrain du pays des lacs de Drawsko. Les éléments du milieu naturel, tels que, les eaux superficielles, le tapis forestier et la formation de la surface terrestre constituent leurs principales valeurs touristiques. Le rôle spécial y est joue par les lacs et les riviéres qui sont une base du développement des formes différentes du tourisme. Ce qui rend possible l'exploitation des valeurs mentionnées c'est l'aménagement touristique, qui au milieu des années quatre-vingt-dix n'était pas au niveau trés élevé. En 199514 objets de couchage et 2 logements disposant de chambres d'hôte y étaient enregistrés.

Leur équipement c'était un héritage transmis par la base touristique des années soixante-dix et quatre-vingts. Pareille est la situation de la base gastronomique, qui, les centres de repos mis à part, était concentrée dans la ville de Zlocieniec (restaurants, bars, cafés). Malgré la situation faible en général, quelques symptômes des changements se faisaient voir. Les propriétaires et les tenanciers privés des objets en se rendant compte que le tourisme peut être une sourse solide des revenus, pour attirer les touristes enlevaient le standard des services offerts (annexes de cuisine supplémentaire, salles de bains, douches, toillettes dans les chambres, salles de jeux, foyers, cabinets de régénération biologique).

Les itinéraires du tourisme pédestre et sur eau et toute la structure de communication demandent la modernisation et l'amélioration.

A la base des recherches faites on a créé le profil du touriste se reposant sur le terrain examiné. Dans la commune de Złocieniec domine le repos en famille. Les touristes âgés de 30-50 ans constituent $72,4 \%$. Ce sont avant tout les parents avec les enfants ou les grands-parents avec les petits-enfants. Ils vivent sous les tentes - $53,1 \%$ (tente et remarque de camping) ou dans les centres de repos - 19,2\%. Ils préparent les repos eux-mêmes - 68,6\%. Les formes du tourisme le plus souvent pratiquées sont: repos sur plage, bains, pêche à la ligne, promenades à pied. Ce sont les habitants des voivodies: de Lódź, de Koszalin, de Legnica, de Bielsko-Biała, de Poznań, de Wrocław, et Kraków qui viennent le plus souvent à Złocieniec.

Outre le but instructif l'article présente l'application pratique des recherches sur le mouvement touristique. Particulièrement important est leur rôle dans la promotion touristique de la commune.

La promotion qui créé l'image congrue joue le rôle primordial en marketing. Avant peu elle était presque inconnue sur ce terrain et à l'epoque du tourisme social superflue. Depuis quelques années les autorités de la commune et les propriétaires des objets touristiques essaient d'attirer sur les propriétaires des objets touristiques essaient d'attirer sur leur terrain le plus de touristes.

Le processus n'est pas facile. Il faut savoir: où promouvoir? comment? quoi? et pour qui? On peut répondre à ces questions en analysant le mouvement touristique sur le terrain concret. Done on peut dire que les recherches sur le mouvement touristique jouent en géographie le même rôle que celles sur le marché en sciences économiques. Sans ces recherches il n'y a pas d’image 
convenable de la ville et de la commune de Złocieniec, il n'y a pas de promotion ni enfin de vrai développement du tourisme.

Traduit par Lucjan Kowalski

\section{SUMMARY}

The article presents the character of the tourist traffic in the town and district of Ztocieniec. The objective of the work was to answer the question who, where and when visits the town and district of Złocieniec, and what the needs, demands and expectations of the tourists are, as well as what consequences it should have for planning the strategy of the promotion of this area.

The source material was collected in July and August 1995 through survey (130 questionnaires were filled in in places of the most intense tourist traffic), area survey in administrative institutions (the Townhall of Złocieniec, Voievodship Office in Koszalin, etc.) and in tourist service establishments (night accommodation and board centres), as well as through direct field observation.

The town and district of Zlocieniec are situated in the area of the Drawskie Lake District. The main tourist assets here are elements of the natural environment: surface waters, forests and the land sculpture. A special role is played by the lakes and rivers, which give the basis for the development of different forms of tourism. An important element which enables tourists to benefit from the assets mentioned above is the tourist infrastructure, which in mid-1990's did not, unfortunately, reach too high a level. In 199514 night accommodation places and 2 houses with guest rooms were registered, whose equipment and furnishing dated back to the tourist infrastructure of the 1970's and 1980's. A similar situation could be observed in the board section, which apart from holiday centres, was concentrated only in the town of Zlocieniec (restaurants, bars, cafes). Despite the generally unfavourable situation, there appeared the first symptoms of changes. Private owners and lessees of tourist objects, seeing in tourism a source of considerable income, are gradually raising the standard of the services they offer (additional kitchenettes, dining annexes, bathrooms, showers, toilets next to the rooms, playrooms, beauty parlours). In this way they are trying to attract the maximum number of tourists.

Modernization and improvement are also required as far as walking and water routes, as well as the whole transport infrastructure are concerned.

On the basis of the research, a model of a tourist resting in the area under study was created. In the Zlocieniec district the family recreation is predominant. The main group of the visitors are tourists between 30 and 50 years of age $-72,4 \%$. They are chiefly parents with children and grandparents with grandchildren. They live in camping areas $-53,1 \%$ (tents, caravans), or in holiday centres $-19,2 \%$, and they choose self-catering $-68,6 \%$. The favourite forms of tourism among this group of people are: going to the beach, bathing, fishing, walking. The visitors arrive mainly from the following voievodships: Łódź, Koszalin, Legnica, Katowice, Bielsko-Biała, Poznań, Wrocław and Cracow.

Apart from the purely cognitive objective, the article also presents the practical application of the research into the tourist traffic. Its role in the tourist promotion of the district is particularly important. Promotion which creates the appropriate image plays the most significant role in marketing. It had been unknown in this area till not so long ago, and in the times of social tourism even unnecessary. For a few years the district authorities and the owners of tourist objects have been trying to attract the maximum numbers of tourists to their area. It is not an easy process, as one has to know where, how, what and for whom to promote. One can find the answers by 
carrying out analyses of the tourist traffic in a given area. It can be stated that research into tourist traffic is for geography what marketing is for economy. Without this research there is no proper image of the town and district of Zlocieniec, there is no promotion, end, eventually, there is no proper development of tourism.

Translated by Ewa Mossakowska 